\title{
Microbial and Sensory Evaluation of Dried Fig (F. carica L.) Cultivars Bellary and Poona
}

\author{
T.S. Manjunath ${ }^{1 *}$, P. Babu ${ }^{2}$, A.N. Bagali ${ }^{3}$ and K.S. Jyadati ${ }^{4}$ \\ ${ }^{1}$ Department of Horticulture, ${ }^{3}$ Department of Horticulture, ${ }^{4}$ Department of Food Science and \\ Nutrition, College of Agriculture, Dharwad, University of Agricultural Sciences, \\ Dharwad, Karnataka, India \\ ${ }^{2}$ Department of Horticulture, College of Agriculture, Hanumanamatti, University of \\ Agricultural Sciences, Dharwad, Karnataka, India \\ *Corresponding author
}

\section{A B S T R A C T}

\begin{tabular}{|l|}
\hline Ke y w or d s \\
$\begin{array}{l}\text { Sensory evaluation, } \\
\text { Dried fig, Quality } \\
\text { attribute }\end{array}$ \\
\hline Article Info \\
\hline $\begin{array}{l}\text { Accepted: } \\
\text { 26 April } 2019 \\
\text { Available Online: } \\
\text { 10 May } 2019\end{array}$ \\
\hline
\end{tabular}

Fresh fruits of two fig cultivars viz. Bellary and Poona subjected various osmotic pretreatments and tray-dried. Dried figs were further assessed to surface microbial population to study the quality of dried product and evaluated for sensory qualities to understand the influence of osmotic pre-treatments on sensory preference for the dried product. Off the fig cultivars, statistically minimum surface count of bacteria $\left(3.64 \times 10^{5} \mathrm{cfu} / \mathrm{g}\right)$, yeast $(1.00 \times$ $\left.10^{3} \mathrm{cfu} / \mathrm{g}\right)$ and mould $\left(0.9710^{3} \mathrm{cfu} / \mathrm{g}\right)$ population and maximum organoleptic scores for appearance (7.07), aroma and flavour (7.14), taste (7.13), texture (7.27) and overall acceptability (7.24) was recorded with dried Bellary figs. Among different osmotic pretreatments, fig fruits treated with $50^{\circ}$ Brix honey for 12 hours registered low bacterial $\left(0.50 \times 10^{5} \mathrm{cfu} / \mathrm{g}\right)$, yeast $\left(0.53 \times 10^{3} \mathrm{cfu} / \mathrm{g}\right)$ and mould population $\left(2.45 \times 10^{3} \mathrm{cfu} / \mathrm{g}\right)$ and greater organoleptic scores for appearance (7.07), aroma and flavour (7.59), taste (7.58), texture (7.79) and overall acceptability (7.67).

\section{Introduction}

Fig (Ficus carica L.) is one of the commercial fruit crops grown in the arid and semi-arid region of the Karnataka. In recent years, the area under fig is gradually increasing, resulting in increased production (Ganapat, 2012). Since it is a season bound crop, increased production has led to seasonal glut in the market fetching uneconomic prices to farmers. Fig fruits being highly perishable need to be consumed either fresh or processed products. In the absence of commercially available and economically viable technology for processing, fig fruits are now being disposed of only through fresh market. This has caused considerable reduction in the price of fresh fruits. Only a little attention has been given to develop the processing technology for fig. Based on the technology available for 
other fruits, few products such as dried fig, fig burfi, syrup and wine has been tried. The post- harvest losses of fresh fig fruits are a major concern, as fruits are very delicate and hence easily damaged during harvesting, handling, and transportation. Further, as fruits have a very thin and delicate skin, the postharvest physiological losses are higher.

The delicate structure of fruit has become an impediment for long distance transport. Hence, nearly 30 per cent of the crop is lost due to improper handling, transportation and storage condition (Madan and Ullasa, 1993). Therefore, processing of fig fruits in to value added products avoids market gut and safeguards the prices and dried figs are becoming increasingly popular creating market demand. Taking all these factors in to account, adopting osmotic dehydration technique in combination with tray- drying method an effort was made in the present investigation to get good quality dehydrated product through sensory and microbial assessment.

\section{Materials and Methods}

The present investigation "Microbial and sensory evaluation of dried figs of cultivars Bellary and Poona" was carried out in the Department of Horticulture, College of Agriculture, Vijayapura, University of Agricultural Sciences, Dharwad, Karnataka during the year 2016-2017. Fruits of fig cultivar Poona were procured from Indian Institute of Horticulture Research (IIHR), Bengaluru and cultivar Bellary were brought from farmers field at Serigeri village, Bellary District, Karnataka. Fig fruits of uniform size, shape and maturity were selected and carefully packed in corrugated fibre boxes (CFB) having provision for ventilation with paper straw as cushioning material, brought for conducting experiment.

\section{Pre-treatments and tray- drying}

Fig fruits of $c v$. Poona and Bellary having uniform colour, size and shape selected and the diseased, bruised, immature, small sized and damaged ones discarded. Stalk of the fruits cut with knife and washed in clean potable water to remove dust and residues of chemicals present on the fruit skin. Before drying, blanching of fruits done to inactivate the enzyme and prevent microbial contamination in subsequent operations. The cleaned fruits were subjected to hot water treatment at $90^{\circ} \mathrm{C}$ for 4 minute, then cooled to room temperature and dipped in 0.2 per cent potassium metabisulphite (KMS) solution for 5 minute followed by 0.25 per cent citric acid for 4 minute and then drained (Rajendra, 2005) to keep the fruits ready for pretreatments.

After blanching and treatment with chemical preservative and antioxidant, Poona and Bellary figs (2 kg each) pre-treated (dipped) with sucrose, honey, date and invert sugar syrup at $50{ }^{0}$ Brix for different duration to study the influence of pre-treatments on quality of dried figs. For drying, pre-treated figs spread uniformly on the trays in a single layer. The loaded trays placed in a tray-dryer and then dehydrated. During the process of drying, the temperature $55 \pm 4^{\circ} \mathrm{C}$ maintained and dried for 46-52 hours to the moisture level of 18-20\%, as per the protocol given by Thonta and Patil (1988). Partially dried fruits, when about 50-60\% moisture removed, taken out and pressed carefully. After drying, the samples packed in poly pouch and kept hermetically sealed under ambient conditions.

\section{Organoleptic evaluation of dried figs}

Organoleptic evaluation of dried figs was carried out by a panel of 10 semi-trained judges consisting of teachers, staff and postgraduate students. The organoleptic characters 
like appearance, aroma and flavour, texture, taste and overall acceptability of dried fig fruits were evaluated based on nine-point hedonic rating scale.

\section{Microbial analysis}

Dried figs of both the cultivars subjected to microbial analysis conducted by dilution plate technique (Shank et al., 1975).

\section{Statistical analysis}

The data on organoleptic characters and microbial population recorded in the experiment subjected to factorial completely randomised design (FCRD). Interpretation of data carried in accordance with Panse and Sukhatme (1985). The level of significance used in ' $\mathrm{F}$ ' test and ' $\mathrm{T}$ ' test was $\mathrm{p}=0.05$ (at 5 $\%$ ). A critical difference (CD) was determined whenever ' $F$ ' test was significant.

\section{Results and Discussion}

\section{Surface microbial population of dried figs}

The data furnished in table 1 shows the bacterial, yeast and mould count of dried figs as influenced by pre-treatments, cultivars and their interaction effects.

\section{Bacterial count}

The results indicated that only pre-treatments had significant effect on bacterial count. The minimum bacterial count was observed in honey $\left(2.45 \mathrm{No} \times 10^{5} \mathrm{cfu} / \mathrm{g}\right)$ pre - treated figs for 12 hours, while, the bacterial count was maximum in untreated sample $\left(4.61 \mathrm{No} \times 10^{5}\right.$ $\mathrm{cfu} / \mathrm{g})$. Non-significant differences registered between cultivars with respect to bacterial count. The highest value for bacterial count was recorded in cv. Poona $\left(3.75 \mathrm{No} \times 10^{5}\right.$ $\mathrm{cfu} / \mathrm{g})$ compared to cv. Bellary (3.64 No $\times 10^{5}$ $\mathrm{cfu} / \mathrm{g})$. Interaction effect between cultivar and pre-treatment also found non-significant However, lower values for bacterial counts were recorded in honey $\left(2.33 \mathrm{No} \times 10^{5} \mathrm{cfu} / \mathrm{g}\right)$ pre - treated Bellary fig for 12 hours, which was on par with honey $\left(2.57\right.$ No $\left.\times 10^{5} \mathrm{cfu} / \mathrm{g}\right)$ pre - treated Poona figs for 12 hours. Greater level of bacterial count was observed in untreated Poona fig (4.62 No $\left.\times 10^{5} \mathrm{cfu} / \mathrm{g}\right)$, which was on par with untreated Bellary fig $\left(4.59 \mathrm{No} \times 10^{5} \mathrm{cfu} / \mathrm{g}\right)$.

\section{Yeast count}

The differences due to pre-treatments were significant with respect to yeast count. The minimum value for yeast count was recorded in honey $\left(0.50 \mathrm{No} \times 10^{3} \mathrm{cfu} / \mathrm{g}\right)$ pre - treated figs for 12 hours and maximum yeast count was registered in untreated sample $(1.51 \mathrm{No} \times$ $\left.10^{3} \mathrm{cfu} / \mathrm{g}\right)$. Whereas, the differences due to cultivars with respect to yeast count was nonsignificant. The highest value for yeast count was recorded in cv. Poona $\left(1.06\right.$ No $\times 10^{3}$ $\mathrm{cfu} / \mathrm{g})$ compared to $\mathrm{cv}$. Bellary $\left(1 \mathrm{No} \times 10^{3}\right.$ $\mathrm{cfu} / \mathrm{g})$. The interaction effect between cultivar and pre - treatments also found nonsignificant. Most yeast count was observed in untreated Poona fig (1.56 No $\left.\times 10^{3} \mathrm{cfu} / \mathrm{g}\right)$, which was on par with untreated Bellary fig $\left(1.46 \mathrm{No} \times 10^{3} \mathrm{cfu} / \mathrm{g}\right)$. Whereas, less of yeast count was recorded in date syrup $(0.48$ No $\times$ $\left.10^{3} \mathrm{cfu} / \mathrm{g}\right)$ pre - treated Poona fig for 12 hours, which was on par with in date syrup (0.52 No $\left.\times 10^{3} \mathrm{cfu} / \mathrm{g}\right)$ pre - treated Poona fig for 12 hours.

\section{Mould count}

Significant difference due to pre-treatments observed with respect to mould count. The minimum value for mould count was recorded honey $\left(0.53 \mathrm{No} \times 10^{3} \mathrm{cfu} / \mathrm{g}\right)$ pre - treated figs for 12 hours, which was on par with date syrup $\left(0.59 \mathrm{No} \times 10^{3} \mathrm{cfu} / \mathrm{g}\right)$ pre - treated figs for 12 hours, whereas, maximum mould count was in untreated sample $\left(1.57\right.$ No $\times 10^{3}$ 
$\mathrm{cfu} / \mathrm{g})$. However, the data with non-significant differences registered between cultivars with respect to mould count. The highest value for mould count was observed in cv. Poona (1.02 No $\left.\times 10^{3} \mathrm{cfu} / \mathrm{g}\right)$ compared to cv. Bellary $(0.97$ No $\left.\times 10^{3} \mathrm{cfu} / \mathrm{g}\right)$. The differences due to interaction between cultivars and pretreatments were also non-significant. The mould count observed maximum in untreated Poona fig $\left(1.60 \mathrm{No} \times 10^{3} \mathrm{cfu} / \mathrm{g}\right)$, which was on par with untreated Bellary fig (1.53 No $\times$ $\left.10^{3} \mathrm{cfu} / \mathrm{g}\right)$. It was minimum in date syrup $\left(0.41 \mathrm{No} \times 10^{3} \mathrm{cfu} / \mathrm{g}\right)$ pre - treated Bellary fig for 12 hours, which was on par with in honey $\left(0.44\right.$ No $\left.\times 10^{3} \mathrm{cfu} / \mathrm{g}\right)$ pre - treated Poona fig for 12 hours in case of cultivar Poona.

\section{Organoleptic characteristics of dried figs}

The organoleptic evaluation of dried figs prepared from cultivar Poona (Fig. 1) and cultivar Bellary (Fig. 2) using different pretreatments, done to assess the consumer preference by a panel of semi-trained judges for appearance, aroma and flavour, taste, texture and overall acceptability. The data on appearance, aroma and flavour, taste, texture and overall acceptability of dried figs as influenced by cultivars, pre - treatments and their interaction effects furnished in table 2.

\section{Appearance}

The data revealed significant differences due to pre - treatments with respect to appearance. Highest score for appearance found in invert sugar (7.74) pre - treated figs for 24 hours, which was on par with date syrup (7.60) pre treated figs for 12 hours and lowest score for appearance found in untreated sample (5.99). Whereas, the difference due to cultivars were found non - significant and highest score for appearance was recorded in cv. Bellary (7.07) compared to cv. Poona (6.82) and also, the interaction effect between cultivar (C) and treatments $(\mathrm{T})$ found non-significant. Score for appearance found maximum in Bellary fig dipped in invert sugar (7.86) for 12 hours, which was on par with Bellary fig pre-treated with sucrose (7.70) for 24 hours and minimum in untreated Poona fig (5.99).

\section{Aroma and flavour}

The data indicated that, cultivars and pretreatments effect differed significantly. Considering the score for pre-treatments, irrespective of cultivars, significantly highest score for aroma and flavour was recorded in honey (7.59) pre - treated figs for 12 hours, while, lowest score was recorded in untreated sample (5.71). However, the organoleptic score for aroma and flavour with respect to cultivars found to be non-significant. The highest score recorded in cv. Bellary (7.14) compared to $\mathrm{cv}$. Poona (6.86). The results for interaction effect due to cultivars and pretreatments also found non-significant and highest score recorded in Bellary fig dipped in honey (7.76) dipped for 12 hours and minimum in untreated Poona fig (5.38).

\section{Taste}

The results revealed that the pre-treatments registered significant effect on taste. Highest score due to pre-treatments, irrespective of cultivars was found in honey (7.58) pre treated figs for 12 hours, which was on par with invert sugar (7.57) pre - treated samples for 24 hours, whereas, lowest score for taste was found in untreated samples (6.14). The sensory scores for taste due to cultivars however found to be non-significant, the cultivar Bellary had maximum score (7.13) compared to cultivar Poona (6.95). The interaction effect between cultivars and treatments with respect to taste also found non-significant, though Bellary fig dipped in honey (7.70) for 12 hours had maximum score while, untreated Bellary fig (6.13) had minimum score. 
Table.1 Effect of pre-treatments and cultivars on bacterial count, yeast count and mould count of dried fig fruits

\begin{tabular}{|c|c|c|c|}
\hline$F_{1}$ - Pre-treatments & $\begin{array}{l}\text { Bacterial count } \\
\left(\mathrm{No} \times 10^{5} \mathrm{cfu} / \mathrm{g}\right)\end{array}$ & $\begin{array}{c}\text { Yeasts count } \\
\left(\mathrm{No} \times 10^{3} \mathrm{cfu} / \mathrm{g}\right)\end{array}$ & $\begin{array}{l}\text { Moulds count } \\
\left(\mathrm{No} \times 10^{3} \mathrm{Cfu} / \mathrm{g}\right)\end{array}$ \\
\hline $\mathbf{T}_{1}$ & 4.61 & 1.51 & 1.57 \\
\hline $\mathbf{T}_{2}$ & 4.10 & 1.31 & 1.18 \\
\hline $\mathbf{T}_{3}$ & 2.45 & 0.50 & 0.53 \\
\hline $\mathbf{T}_{4}$ & 3.31 & 0.60 & 0.59 \\
\hline $\mathbf{T}_{5}$ & 4.04 & 1.25 & 1.12 \\
\hline Mean & 3.70 & 1.03 & 0.99 \\
\hline S. Em. \pm & 0.18 & 0.11 & 0.08 \\
\hline CD at $5 \%$ & 0.56 & 0.30 & 0.25 \\
\hline \multicolumn{4}{|l|}{$\mathbf{F}_{2}-$ Cultivars } \\
\hline $\mathbf{C}_{1}$ & 3.75 & 1.06 & 1.02 \\
\hline $\mathbf{C}_{2}$ & 3.64 & 1.00 & 0.97 \\
\hline Mean & 3.70 & 1.03 & 1.00 \\
\hline S. Em. \pm & 0.11 & 0.07 & 0.05 \\
\hline CD at $5 \%$ & NS & NS & NS \\
\hline \multicolumn{4}{|c|}{ Treatments interaction } \\
\hline $\mathbf{T}_{1} \mathbf{C}_{1}$ & 4.62 & 1.56 & 1.60 \\
\hline $\mathbf{T}_{1} \mathbf{C}_{2}$ & 4.59 & 1.46 & 1.53 \\
\hline $\mathbf{T}_{2} \mathbf{C}_{1}$ & 4.30 & 1.34 & 1.16 \\
\hline $\mathbf{T}_{2} \mathbf{C}_{2}$ & 3.89 & 1.29 & 1.20 \\
\hline $\mathbf{T}_{3} \mathbf{C}_{1}$ & 2.57 & 0.64 & 0.44 \\
\hline $\mathbf{T}_{3} \mathbf{C}_{2}$ & 2.33 & 0.55 & 0.62 \\
\hline $\mathbf{T}_{4} \mathbf{C}_{1}$ & 3.65 & 0.48 & 0.76 \\
\hline $\mathbf{T}_{4} \mathbf{C}_{2}$ & 2.97 & 0.52 & 0.41 \\
\hline $\mathbf{T}_{5} \mathbf{C}_{1}$ & 3.89 & 1.30 & 1.14 \\
\hline $\mathbf{T}_{5} \mathbf{C}_{2}$ & 4.18 & 1.20 & 1.11 \\
\hline Mean & 4.10 & 1.44 & 1.41 \\
\hline S. Em. \pm & 0.26 & 0.15 & 0.12 \\
\hline CD at $5 \%$ & NS & NS & NS \\
\hline
\end{tabular}

Note: NS - Non-significant

$\mathrm{T}_{1}$ - Control (Untreated)

$\mathrm{T}_{2}$ - Fruits dipped in $50^{\circ}$ Brix of Sucrose for 24 hours

$\mathrm{T}_{3}$ - Fruits dipped in $50^{\circ}$ Brix of Honey for 12 hours

$\mathrm{T}_{4}$ - Fruits dipped in $50^{\circ}$ Brix of Date syrup for 12 hours

$\mathrm{T}_{5}$ - Fruits dipped in $50^{\circ}$ Brix of Invert sugar (50\% glucose $+50 \%$ fructose) for 24 hours

$\mathrm{C}_{1}$ - Poona

$\mathrm{C}_{2}$ - Bellary 
Int.J.Curr.Microbiol.App.Sci (2019) 8(5): 2493-2503

Table.2 Effect of pre-treatments and cultivars on sensory characteristics of dried fig fruits

\begin{tabular}{|c|c|c|c|c|c|}
\hline$F_{1}-$ Pre-treatments & Appearance & $\begin{array}{c}\text { Aroma and } \\
\text { flavour }\end{array}$ & Taste & Texture & $\begin{array}{c}\text { Overall } \\
\text { acceptability }\end{array}$ \\
\hline $\mathbf{T}_{1}$ & 5.99 & 5.71 & 6.14 & 6.09 & 5.92 \\
\hline $\mathbf{T}_{2}$ & 7.60 & 7.21 & 7.00 & 7.25 & 7.55 \\
\hline $\mathbf{T}_{\mathbf{3}}$ & 7.28 & 7.59 & 7.58 & 7.79 & 7.67 \\
\hline $\mathbf{T}_{4}$ & 6.14 & 7.27 & 6.98 & 7.56 & 6.76 \\
\hline $\mathbf{T}_{5}$ & 7.74 & 7.25 & 7.57 & 7.35 & 7.65 \\
\hline Mean & 6.95 & 7.00 & 7.05 & 7.21 & 7.11 \\
\hline S. Em. \pm & 0.13 & 0.13 & 0.46 & 0.08 & 0.08 \\
\hline CD at $5 \%$ & 0.37 & 0.40 & 1.37 & 0.23 & 0.25 \\
\hline \multicolumn{6}{|l|}{$\mathbf{F}_{2}-$ Cultivars } \\
\hline $\mathbf{C}_{1}$ & 6.82 & 6.86 & 6.95 & 7.13 & 6.97 \\
\hline $\mathbf{C}_{2}$ & 7.07 & 7.14 & 7.13 & 7.27 & 7.24 \\
\hline Mean & 6.95 & 7.00 & 7.04 & 7.20 & 7.11 \\
\hline S. Em. \pm & 0.08 & 0.08 & 0.29 & 0.05 & 0.05 \\
\hline CD at $5 \%$ & NS & NS & NS & NS & 0.15 \\
\hline \multicolumn{6}{|c|}{ Treatments interaction } \\
\hline $\mathbf{T}_{1} \mathbf{C}_{1}$ & 5.99 & 5.38 & 6.15 & 5.90 & 5.72 \\
\hline $\mathbf{T}_{1} \mathbf{C}_{2}$ & 6.25 & 6.04 & 6.13 & 6.28 & 6.11 \\
\hline $\mathbf{T}_{2} \mathbf{C}_{1}$ & 7.50 & 7.17 & 6.81 & 7.09 & 7.50 \\
\hline $\mathbf{T}_{2} \mathbf{C}_{2}$ & 7.70 & 7.24 & 7.17 & 7.40 & 7.60 \\
\hline $\mathbf{T}_{3} \mathbf{C}_{1}$ & 7.19 & 7.42 & 7.52 & 7.92 & 7.55 \\
\hline $\mathbf{T}_{3} \mathbf{C}_{2}$ & 7.37 & 7.76 & 7.61 & 7.65 & 7.78 \\
\hline $\mathbf{T}_{4} \mathbf{C}_{1}$ & 6.10 & 7.19 & 6.89 & 7.52 & 6.52 \\
\hline $\mathbf{T}_{4} \mathbf{C}_{2}$ & 6.18 & 7.35 & 7.06 & 7.60 & 7.00 \\
\hline$T_{5} C_{1}$ & 7.63 & 7.18 & 7.45 & 7.24 & 7.60 \\
\hline $\mathbf{T}_{5} \mathbf{C}_{2}$ & 7.86 & 7.31 & 7.70 & 7.46 & 7.70 \\
\hline Mean & 6.95 & 7.00 & 7.08 & 7.21 & 7.11 \\
\hline S. Em. \pm & 0.18 & 0.18 & 0.66 & 0.12 & 0.11 \\
\hline CD at $5 \%$ & NS & NS & NS & NS & NS \\
\hline
\end{tabular}

Note: NS - Non significant 
Fig.1 Tray-dried Poona fig fruits

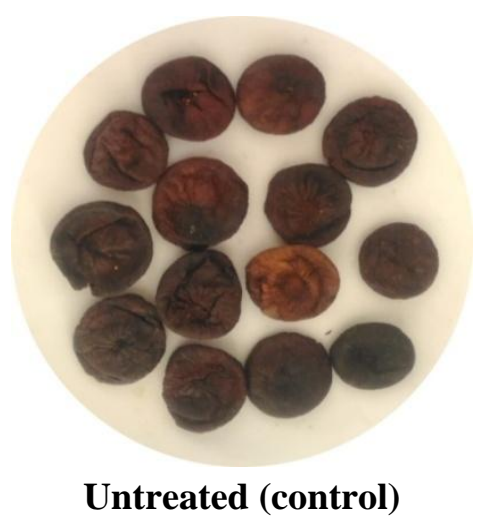

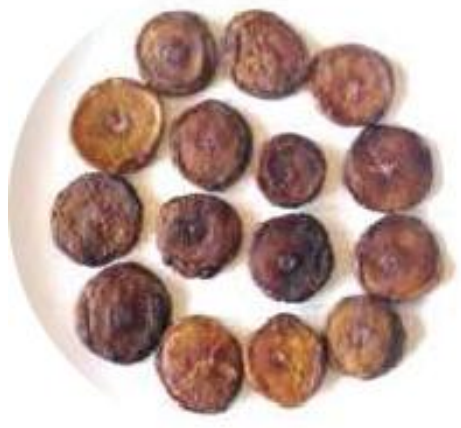

Sucrose $\left(50^{\circ}\right.$ Brix $)$ pre- treatment

for 24 hours

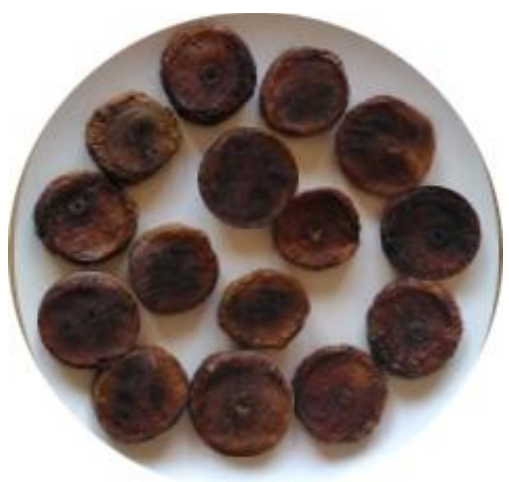

Date syrup $\left(50^{\circ}\right.$ Brix $)$ pre- treatment for 12 hours

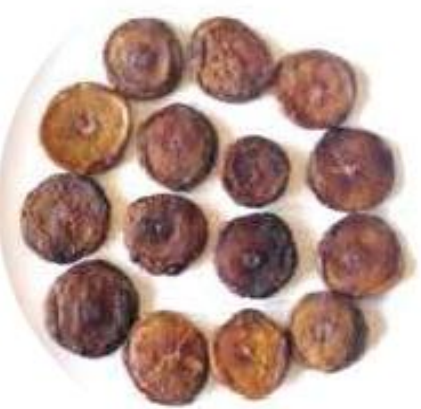

Honey $\left(5^{\circ}\right.$ Brix $)$ pre-treatment for 12 hours

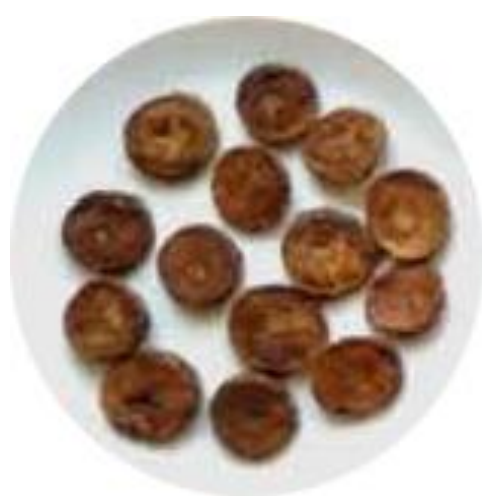

Invert sugar $\left(50^{\circ}\right.$ Brix $)$ pre-treatment for 24 hours 
Fig.2 Tray-dried bellary fig fruits

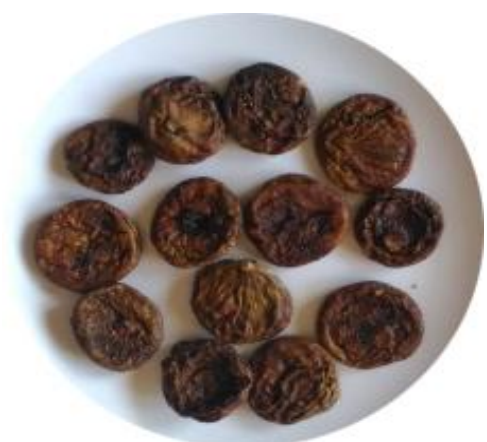

Untreated (control)

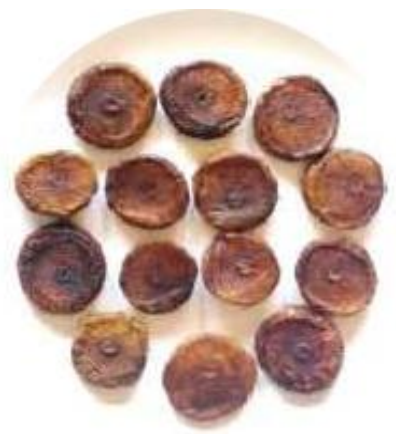

Sucrose $\left(5^{\circ}\right.$ Brix $)$ pre- treatment for 24 hours

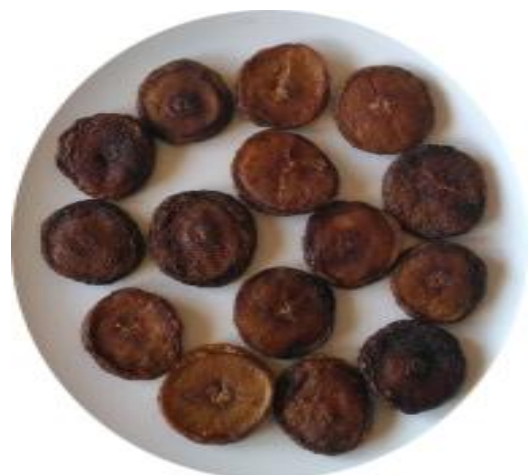

Date syrup $\left(5^{\circ}\right.$ Brix $)$ pre- treatment for 12 hours

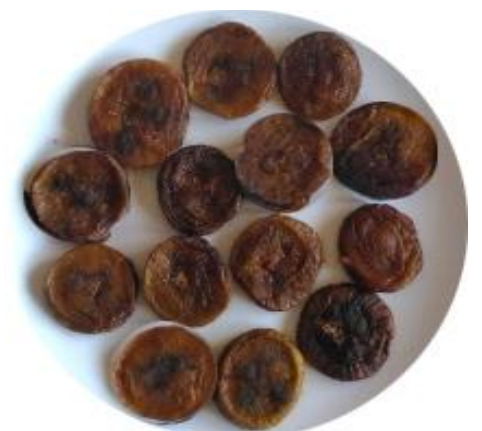

Honey $\left(50^{\circ}\right.$ Brix) pre-treatment for 12 hours

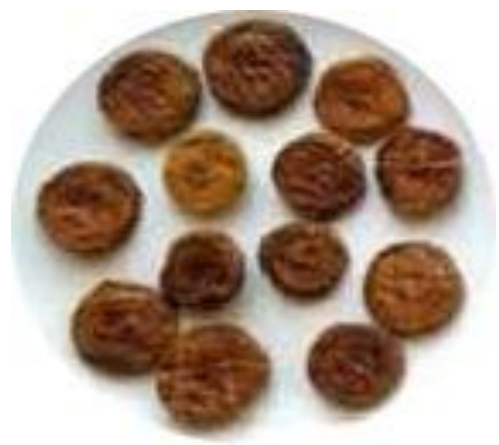

Invert sugar $\left(5^{\circ}\right.$ Brix $)$ pre-treatment for 24 hours 


\section{Texture}

The data presented in the table depicted that the pre-treatments effects were differed significantly. Irrespective of cultivars, the highest score for texture found in honey (7.79) dipped figs for 12 hours, which was on par with date syrup (7.56) dipped samples for 12 hours, while untreated samples (6.09) recorded the lowest score for texture. On the other hand, there was no significant effect found due to cultivars. However, maximum score for texture recorded in cv. Bellary (7.27) and minimum in cv. Poona (7.13). Interaction effect between cultivars and pretreatments for the texture of dried figs were also found non-significant; figs pre - treated (7.92) with honey for 12 hours had maximum score (7.70) and minimum score for texture recorded in untreated Poona fig (5.90).

\section{Overall acceptability}

The results indicated that the pre-treatments and cultivars effects differed significantly. Considering pre-treatment scores, irrespective of cultivars, noticed that significantly higher score in honey (7.67) pre - treated figs for 12 hours, which was on par with invert sugar (7.65) pre - treated samples for 24 hours, and least score for overall acceptability found in untreated fig samples (5.92). Score for overall acceptability for cultivars, irrespective of pre-treatments, also found to be significant. Highest score for overall acceptability registered in cv. Bellary (7.24) compared to cv. Poona (6.97). Notwithstanding, nonsignificant differences were registered due to interaction effect between cultivars and pretreatments, Bellary fig (7.78) pre - treated in honey for 12 hours had maximum score, which was on par with invert sugar pretreated (7.70) Bellary fig and untreated Poona fig (5.72) had minimum score for overall acceptability.

\section{Surface microbial population of dried figs}

The behaviour of the different groups of microorganisms immediately after processing was quite different and depends upon the type of pre-treatments used before dehydration. Thus, the trend of decreasing the total counts of bacteria, yeast and moulds well correlated with the type of osmotic solution used in the pre-treatment before dehydration (Manal and Gend, 2014).

Among the various pre - treatments tried, least microbial population recorded in honey pre - treated dried figs for 12 hours (Table 1). This may be due to anti-microbial activity of honey, results in inhibition of microbial growth. While, highest value for microbial population was observed in untreated samples. This might be due to nonpreservative action in control samples, which resulted in more microbial population. However, there were no significant differences between the cultivars for the presence of microbes in dried figs though it was more in cv. Poona. This might be due to high moisture content in Poona figs compared to that of Bellary figs. Sowjanya and Rao (2004) also opined that moisture plays important role in growth of microbial organisms on dried products. Naikwadi et al., (2010) reported similar results in dried fig fruit. These results show that the immersion of figs in different osmotic solutions before dehydration was efficient in reducing the total counts of bacteria, yeasts and moulds.

\section{Organoleptic characteristics of dried figs}

The merits of any consumable products depend not only on its composition and nutritive value, but also on sensory quality. Evaluation of sensory quality of a product is an important tool for deciding the consumer acceptability. Appearance, aroma, flavour, texture, taste and overall acceptability are the 
important sensory traits, which decide the consumer acceptability of any product, in general. Therefore, the sensory evaluation of dehydrated fig fruits carried out by a panel of judges consisting of semi-skilled persons / staff of the campus.

In the present investigation, the results of sensory evaluation of dehydrated fig fruits presented in table 2 have clearly indicated that all the pre-treatments helped to obtain organoleptically acceptable dried fig.

Among the pre - treatments tried, the fig fruits pre-treated with honey for 12 hours showed the highest sensory scores for aroma and flavour $(7.59 \%)$, taste $(7.58 \%)$, texture (7.79 $\%)$ and overall acceptability (7.67 \%). This might attributed to natural properties of honey flavour, sugar content and sugar: acid ratio influencing consumer acceptance for these organoleptic parameters.

The consumer acceptability of dried fruit directly related to their aroma and flavour and texture (Abano and Sam-Amoah, 2010). The moisture content in honey pre-treated samples influenced texture of dried fig that will result in softness of the product. This overall preference for honey pre -treated dried figs could attributed to the fact that sugar profiles of honey, which results sweet in taste. The organoleptic score for appearance (7.86) was highest in invert sugar pre- treated figs for 24 hours and lowest in untreated samples (5.99) irrespective of the cultivars. This might be due to sugar crystallization on the surface of dried figs (Naikwadi et al., 2010). Conversely, the position of the control in the hedonic rating scale indicates that pretreatments had tremendous influence on the consumer acceptance of the dried products.

The scores for appearance, aroma and flavour, taste, texture and overall acceptability showed non-significant differences among cultivars. Highest organoleptic scores obtained in cv.
Bellary $(7.07,7.14,7.13,7.27$ and 7.24 for appearance, aroma and flavour, taste, texture and overall acceptability, respectively) to that of cv. Poona $(6.82,6.86,6.95,7.13$, and 6.97, respectively). This might be attributed to varietal characteristics of fruits.

Non-significantly highest score for interaction effect among cultivars and pre-treatments for appearance was (7.86) in invert sugar pretreated Bellary cultivar for 24 hours and minimum in untreated Poona fig (5.99). Highest score for aroma and flavour (7.76) and overall acceptability (7.78) found in Bellary fig pre-treated with honey for 12 hours and for taste (7.70) in Bellary fig pretreated with invert sugar for 24 hours while, maximum score for texture (7.92) found in Poona fig pre-treated with honey for 12 hours. However, minimum sensory scores given to untreated Poona figs (5.99, 5.38, 5.90, and 5.72), respectively for appearance, aroma and flavour, texture and overall acceptability. While, for taste (6.13), it was minimum in untreated Bellary figs. Fruits and vegetables flavour depends upon taste (balance between sweetness and sourness or acidity, and low or no astringency) and aroma (concentrations of odour-active volatile compounds) (Kader, 2008). Although taste and aroma are well integrated in their contribution to the overall flavour, aroma is often considered to play a dominant role in flavour (Goff and Klee, 2006).

From the above results it could be concluded that better quality dried fig with good overall acceptability can be obtained when Bellary figs pre- treated with $50^{\circ}$ Brix with honey for 12 hours.

\section{Acknowledgement}

Authors are heartily thankful to the faculty of the Department of Horticulture, College of Agriculture, Dharwad, University of Agricultural Sciences, Dharwad and for 
providing all the facilities and support to conduct the research program.

\section{References}

Abano, E. E., Sam-Amoah, L. K., Owusu, J. and Engmann, F. N., 2010, Effects of ascorbic acid, salt, lemon juice, and honey on drying kinetics and sensory characteristic of dried mango. J. Food Sci. Technol. 5(1): 1 - 1.

Ganpat, D. D., 2012. The economic impact of fig production on dry land farmers in Pune district: with special reference to Purandar Taluka. Ph.D. (Agri) Thesis, Tilak Maharashtra Vidyapeeth, Pune, India.

Madan, M. S. and Ullasa, B. A., 1993, Post harvest losses in fruits. IV Ed. Advances in Horticulture. Malhotra Publishing House New Delhi, (1): 1795 - 1810 .

Manala, E and Gend. 2014, Evaluation of quality attributes of dehydrated figs prepared by osmotic- drying process, Egypt J. Agric. Res. 92(1): 337 - 347.

Naikwadi, P. M., Chavan, U. D., Pawar, V. D. and Amarowicz, R., 2010 Studies on dehydration of figs using different sugar syrup treatments, J. Food. Sci. Tech. 47(4): 442-445.
Panse, V. G. and Sukatme, P. V., 1985, Statistical methods for Agricultural workers, ICAR, New Delhi. 2: 152 155.

Sowjanya, P. and Rao, V. P., 2004, Studies on quality of solar and tray dried figs. M.Sc. (Home Science) Thesis, Acharya Ranga Univ. Agric. Sci., Hyderabad (India).

Rajendra, K., 2005, Dehydration of fig fruits. M. Sc. (Hort.) Thesis, Univ. Agric. Sci., Dharwad.

Goff, S. A., and Klee. H. J., 2006, Plant volatile compounds: sensory cues for health and nutritional value. J. Food Sci., 311, 815 - 819 .

Kader, A. A., 2008, Flavour quality of fruits and vegetables. J. Sci. Food Agric., 88: 1863 - 1868.

Shank, C. R., Duguid, J. P., Marmion, B. P. and Swain, R. H. A., 1975, Medical Microbiology. The practice of medical microbiology, Churst II Livingstone, Edinburgh, London and New York. pp. $306-310$.

Thonta, G. T. and Patil, V. K., 1988, Studies on drying of Fig fruits (Ficus carica L.). Indian Food Packer. 42(4): 94 99.

\section{How to cite this article:}

Manjunath, T.S., P. Babu, A.N. Bagali and Jyadati, K.S 2019. Microbial and Sensory Evaluation of Dried Fig ( $F$. carica L.) Cultivars Bellary and Poona. Int.J.Curr.Microbiol.App.Sci. 8(05): 2493-2503. doi: https://doi.org/10.20546/ijcmas.2019.805.294 